\title{
Uluslararası Göç Yönetim ve Entegrasyonu, Türkiye Örneklemesi
}

\section{The Management and Integration of International Migration, Sampling of Turkey}

$\ddot{O} z$

Dünyada artan iç savaşlar, sosyoekonomik dalgalanmalar, tabii afetler etkisiyle meydana gelen kıtlık, uluslararası göç dalgasının tetikleyici unsurları arasında yer almaktadır. Ekonomi, dünya genelinde uluslararası göçten hem en çok etkilenen hem de etkileyen alanlardan biridir. Göçmen ve mültecilerin ayrıldıkları ve ulaştıkları ülkelerin, sosyal ve ekonomik motivasyonlarında meydana gelen değişimler Sanayi Devriminden bu yana izlenebilir durumdadır. Mülteci entegrasyonun ev sahibi ülke ekonomisine getirdiği etkilerin neler olduğu, kısa ve uzun dönemde nasıl farklılaştırabileceği, ülke ekonomilerine bir yük olmaktan ziyade katkı sunar hale getirilebilmesi, Türkiye ekonomisi örneklemesi, göç yönetimi ve politika önerileri ile sunulacaktır. Uluslararası göçün ev sahibi ülke üzerinde sosyolojik ve ekonomik etkiler bırakması, dünyada en fazla mülteciye ev sahipliği yapan Türkiye için de önem arz etmektedir. Yapılan çalışmalar ve deneyimler incelendiğinde genel olarak ev sahibi ülkenin stratejik politikalar ortaya koyması gerektiği, göçün oluşturduğu maliyetlerin ev sahibi ülkenin sosyal yaşamla beraber ekonomisini de orta ve uzun dönemde etkilediği görülmektedir.

\section{Abstract}

Famine derived from the increasing civil wars, socioeconomic fluctuations and natural disasters all around the world are among the triggering factors of the international migration wave. Worldwide, economy is one of the areas that both has an impact and most affected by international migration. Since the Industrial Revolution, the changes taking place with social and economic motivations of the countries that the refugees leave from and arrive in have been traceable. What the effects of refugee integration are on the economy of the host country, what alterations it would make in short and long term, how it would be transformed into something beneficial rather than a burden on the economy of the country, and economy sampling of Turkey are presented with migration management and policy recommendations. The fact that the international migration leaves sociological and economic effects on the host country is highly important for Turkey, hosting the most refugees around the world. When the studies and experiences are examined, it is observed that the host country should develop strategic policies in general, and the costs caused by migration affect the economy of the host country in the medium and long term as well as the social life.

\section{Giriş}

İnsanların yerleşik toplumlar haline gelmeden önce yaşam biçimi olan göçün insanlık tarihi kadar eski olduğu bilinmektedir. Son yüzyılda, özellikle İkinci Dünya Savaşı sonrası, ülkelerin ekonomik koşullarında meydana gelen değişiklikler, tabii afetler gibi unsurların oluşturduğu geçici veya kalıcı göç dalgaları, kimi zaman da ülkelerin siyasi, güvenlik, emek ve sermaye koşullarında oluşan değişiklikler nedeni ile gerçekleşen iç ve diş göçler önemli ve çözülmesi zor konular olarak izlenmektedir. Türkiye, son yıllarda gerçekleştirdiği ekonomik, siyasi ve kültürel iyileştirmeleri nedeni ile göçmenler için transit ülke olmaktan öte hedef ülke haline gelmiştir. Ancak, Ortadoğu ülkelerinin siyasi, ekonomik ve sosyolojik dalgalanmaları sonucu meydana gelen iç savaşlar, özellikle sınır komşumuz Suriye' de meydana gelen değişiklikler, göç veren ve göç alan ülkeler için ekonomik değişiklikleri, göç yönetimi ve entegrasyon sorunlarını da beraberinde getirmektedir. 
Çalışma üç bölümden oluşmaktadır. İlk bölümde kavramsal takdimler, göçün nedenleri ve etkileri ile sunulurken, ikinci bölümde dünyada bilinen büyük göçler küresel yansımaları ile incelenmiştir. Göçün yüzyıllardır oluşturduğu tehditlerin ülkeler, siyasi yapılar, ekonomiler, demografik ve kültürel yapılar üzerindeki etkileri, göçün yönetimi ve entegrasyonu sayesinde oluşacak kazanımlar, Türkiye örneği ile üçüncü bölümde yer alırken oluşturulan çözüm ve politika önerileri sonuç bölümünde sunulmaktadır.

\section{Kavramlar, Nedenler, Etkiler}

\subsection{Göç, Mülteci, Göçmen, Sı̆̆ınmacı Kavramı}

Nüfusun yerleşimini değiştirerek coğrafi olarak bir yerden bir başka yere, bir yaşam alanından başka bir yaşam alanına doğru yer değiştirmesi (Gresle, 2000:238), bir bölge veya ülkeden başka birine yer değiştirmesi (Gilles, 2002:157), şeklinde verilen göç kavramı tanımlarında ortak nokta, kat edilen bir alan (iç-dış), zaman (geçici- kalıc1), akışın boyutu, göç etme nedeni (gönüllü-zorunlu) ve hukuksal boyut (yasal-yasadışı) olmaktadır (Boudon v.d., 1997:146-147). Niteliklerine göre tanımlama yapıldığı zaman da işgücü ve beyin göçü sınıflandırması yapılmaktadır (Murat ve Taşesenlioğlu, 2009:20). Kofman ise, insanların sadece yaşamlarını sürdürdükleri yerin değişmesinin yanı sıra hem sosyoekonomik hem de kültürel değişimlerine de dikkat çekerek, göç kavramını farklı insanların birbirinden başka sebeplerle yaşamlarını sürdürmekte oldukları yeri kısa ya da uzun bir zaman için terk etmesi olarak tanımlamaktadır (Kofman, 1999:117). Pek çok neden ve biçimde yaşadıkları yeri değiştiren insanlar, uluslararası tanımlara göre mülteci, sığınmacı, göçmen olarak adlandırılmaktadır.

Mülteci; Cenevre Sözleşmesi, 1951 sayılı Mültecilerin Hukuki Statüsü, kimlerin mülteci sayılacağını "ırkı, dini, tabiiyeti, belli bir toplumsal gruba mensubiyeti veya siyasi düşünceleri yüzünden, zulme uğrayacağından haklı sebeplerle korktuğu için vatandaşı olduğu ülkenin dışında bulunan ve bu ülkenin korumasindan yararlanamayan ya da söz konusu korku nedeni ile yararlanmak istemeyen yahut tabiiyeti yoksa ve bu tür olaylar sonucu önceden yaşadığı ikamet ülkesinin dişında bulunan, oraya dönemeyen veya söz konusu korku nedeni ile dönmek istemeyen şahıslardır" (Birleşmiş Milletler Mülteciler Yüksek Komiserliği ve İçişleri Bakanlığı, 2005: 59) şeklinde tanımlarken, Göç İdaresi Genel Müdürlüğgü' nün çalışmalarıyla, Türkiye mülteciyi "Avrupa ülkelerinde meydana gelen olaylar nedeniyle; ırkl, dini, tabiiyeti, belli bir toplumsal gruba mensubiyeti veya siyasi düşüncelerinden dolayı zulme uğrayacağından hakl sebeplerle korktŭ̆u için vatandaşı olduğu ülkenin dışında bulunan ve bu ülkenin korumasından yararlanamayan ya da söz konusu korku nedeniyle yararlanmak istemeyen yabanclya veya bu tür olaylar sonucu önceden yaşadığ̆ ikamet ülkesinin dışında bulunan, oraya dönemeyen veya söz konusu korku nedeniyle dönmek istemeyen vatansız kişiye statü belirleme işlemleri sonrasında verilen statü" olarak tanımlamıştır. Her iki tanımda ortak ifade, "yabancının mülteci statüsü kazanabilmesi için bahsedilen sebeplerden dolayı zulme uğramaları veya tehlikeye maruz kalmaları ya da kendilerini böyle bir tehlike içinde hissetmeleri gerekmektedir" şeklindedir.

Göçmen; Ekonomik veya içinde bulunduğu koşullardan memnun olmadığı için, ülkesini terk ederek yasal veya yasal olmayan yollarla başka bir ülkeye giren kişiler göçmen olarak adlandırılmaktadır. Mültecilik hakkı ve statüsünden faydalanamamaktadırlar (Ziya, 2012:232).

Sığınmacı; Cenevre Sözleşmesi, 1951 sayılı Mültecilerin Hukuki Statüsü, kimlerin mülteci sayılacağını "ırkı, dini, tabiiyeti, belli bir toplumsal gruba mensubiyeti veya siyasi düşünceleri yüzünden, zulme uğrayacă̆ından haklı sebeplerle korktuğu için vatandaşı olduğu ülkenin dışında bulunan ve bu ülkenin korumasindan yararlanamayan ya da söz konusu korku nedeni ile yararlanmak istemeyen yahut tabiiyeti yoksa ve bu tür olaylar sonucu önceden yaşadı̆̆ı ikamet ülkesinin dışında bulunan, oraya dönemeyen veya söz konusu korku nedeni ile dönmek istemeyen, henüz göç ettikleri ülkenin resmi makamlarmca kendilerine mültecilik hakkı tanınmamış şahıslardır" (Barkın, 2014:335) şeklinde tanımlamıştır.

\subsection{Göçün Nedenleri}

Göçün toplumsal, siyasal ve ekonomik değişimlerin sonucunda ortaya çıkmış olması, göçün bir sonuç olduğunun göstergesi olmakla beraber, bulunduğu katkılardan dolayı da göç aynı zamanda bir neden olarak görülmelidir (İçduygu ve Sirkeci, 1999:250). Kane (1995:16) ise göç, ister sonuç ister 
neden olarak nitelendirilsin veya hangi amaçla yapılırsa yapılsın, göçün bağlı olduğu toplumda sosyal, ekonomik ve siyasi etkiler bırakmakta olduğunu dile getirir.

İnsanlar, tarihin hemen her döneminde, çeşitli nedenlerle, köklendikleri, yaşadıkları alan, coğrafya, maddi ve manevi varlıklarını terk etmek durumunda kalmışlar veya bu değişim için tercih kullanmışlardır. Doğa olayları, tabii afetler etkisi ile yapılan göç, sanayi devrimi ile anlam değiştirmiş, sosyal ve ekonomik koşullar önemli hale gelmiştir (Keleş, 1996:6). Dolayısı ile, gönüllü göç eden insan sayısının artması ve daha kolay tercih belirleme sebepleri arasında teknoloji, haberleşme ve ulaştırma faaliyetlerinin gelişmesinin de etkisi bulunmaktadır (Sencer, 1979:28). 2000'li yıllarda tüm dünyayı etkisi altına alan göç hareketliliği, 2010'ların başında yaşanan Arap Baharı ve özellikle Suriye ayağı, ekonomik, siyasi ve güvenlik nedeni ile yapılan zorunlu göçler arasındaki farklılık, şiddet ve etkilerini daha belirgin hale getirmiştir.

Tablo 1. Göç Nedenleri (Mülteci-Göçmen-Sığınmacı)

\begin{tabular}{|l|c|c|c|}
\hline & Mülteci & Göçmen & Sığınmacı \\
\hline Neden & Zorunlu & Gönüllü & Zorunlu \\
\hline Amaç & $\begin{array}{c}\text { Yaşamlarına gelecek } \\
\text { zarardan korunmak için } \\
\text { güvenli bir ülkeye, mal } \\
\text { varlıklarını geride } \\
\text { birakarak iltica eder. }\end{array}$ & $\begin{array}{c}\text { Ekonomik, sosyal, kültürel, } \\
\text { bilimsel nedenlerle daha rahat } \\
\text { etmek için ülkesinden ayrılarak } \\
\text { tercih ettiği yere gider. }\end{array}$ & $\begin{array}{c}\text { Yaşamlarına gelecek zarardan } \\
\text { korunmak için güvenli bir ülkeye, mal } \\
\text { varlıklarını geride bırakarak iltica eder. }\end{array}$ \\
\hline Araç & $\begin{array}{c}\text { Ani kararla, zor şartlar } \\
\text { altında, resmi bir belgesi } \\
\text { olmaksızın yer değiştirir. }\end{array}$ & $\begin{array}{c}\text { Uygun araçlar ve resmi belgeye } \\
\text { sahiptir. }\end{array}$ & $\begin{array}{c}\text { Ani kararla, zor şartlar altında, resmi } \\
\text { bir belgesi olmaksızın yer değiştirir. }\end{array}$ \\
\hline
\end{tabular}

Kaynak: https:/ / www.resmigazete.gov.tr/arsiv/5Eylül1961 :5028-9 verileri ile yazar tarafından oluşturulmuştur.

\subsection{Göçün Etkileri}

Ülkelerin, siyasal iktidarların, yetkililerin kimi zaman karşılamada zorlandığı ya da karşılayamadığı, yönetemediği kitlesel göç hareketleri, mekânsal, sosyal ve siyasal olarak pek çok karmaşık problemin oluşmasına neden olmaktadır (Li ve Frieze, 2012:5-8).

Göç, göç eden birey için gerilim, stres, güvenlik kaygısı, psikolojik travma oluşturmasının yanı sıra, göç eyleminde taraf olan bireyler, toplumlar, ve ülkeler arasında ilişki ve etkileşimi kültürel geçirgenliği geliştirirken, ekonomik, sosyal, güvenlik ve siyasal alanda karmaşıklıklara, kutuplaşma ve radikalleşmenin ortaya çıkmasına da neden olmaktadır.

Göç, dinamik ve çok yönlü bir harekettir. İlk algı, tek yönlü bir hareket gibi görünse bile ekonomi ve beraberinde sosyal sermayeye etkileri nitelemenin doğruluğunu gösterir. Göç veren/kaynak ülke ve göç alan/hedef ülkelerde meydana gelen ekonomik sorunların çoğunda göçmenler sebep gösterilirken, hedef ülkeler göçmenlerin işsizliğe yol açtığını, ücretleri düşürdüğünü, kaynak ülkeler ise beyin göçü ile suçlamaktadır.

Tablo 2. Göçün Etkileri

\begin{tabular}{|c|c|c|c|}
\hline & Göç Veren (Kaynak) Ülke & Transit Ülke & Göç Alan (Hedef) Ülke \\
\hline Ekonomik & $\begin{array}{l}\text { Ülkede nüfus yoğunluğu ve } \\
\text { istihdam sorunu azalırken; } \\
\text { bireysel, toplumsal, ulusal ve } \\
\text { uluslararası seviyede } \\
\text { tüketim, sağlık, eğitim, } \\
\text { sosyalleşme, altyapı, yatırım, } \\
\text { kalkınma gibi alanlarda } \\
\text { yapılan harcamalarda iş̧ii } \\
\text { gelirleri* katkı sunmaktadır. }\end{array}$ & $\begin{array}{l}\text { Nihai ülkeye varıncaya kadar } \\
\text { beklenilen süre içinde göçmenin } \\
\text { kaçak çalışması sonucu ülkede } \\
\text { vergi kaybı, kaçak iş } \\
\text { bulamayanların yarattı̆̆ } \\
\text { güvenlik sorunu, yakalanan } \\
\text { göçmenlere yapılan masraflar } \\
\text { nedeni ile hazinenin zararı söz } \\
\text { konusudur. }\end{array}$ & $\begin{array}{l}\text { İşücü açığı düşük maliyetli işçi ile } \\
\text { kapanırken, üretim ve sanayi } \\
\text { verimliliği sağlanmaktadır. Yerli iş } \\
\text { gücü niteliğini yukarı yönlü } \\
\text { geliştirilmektedir. }\end{array}$ \\
\hline $\begin{array}{l}\text { Kültür, Bilgi } \\
\text { \& Teknoloji }\end{array}$ & 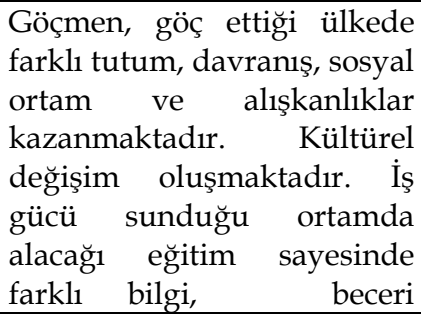 & Karmaşa. & $\begin{array}{l}\text { Göçmen, beraberinde getirdiği } \\
\text { alışkanlık ve kültürüne sıkıca bağlı } \\
\text { kaldığı sürece yerel toplum üzerinde } \\
\text { tepkisel etkiler oluşturmakta, kültür } \\
\text { geçirgenliği gözlemlenmektedir. } \\
\text { Nitelik olarak, kalifiye ve/veya } \\
\text { eğitimli insan gücünün göçü }\end{array}$ \\
\hline
\end{tabular}




$$
\begin{aligned}
& \text { edinebilmektedir. Yeni bir dil } \\
& \text { öğrenmektedir. } \\
& \text { Nitelik olarak, kalifiye } \\
& \text { ve/veya eğitimli insan } \\
& \text { gücünün göçü gerçekleşirse, } \\
& \text { ülke beyin göçü vermiş olur. }
\end{aligned}
$$

Kaynak: Yazar tarafından oluşturulmuştur.

İşgücü piyasalarının özelliklerine bağlı olarak pek çok ülke, insan sermayesine ihtiyaç duyduğunda belirlediği kriterlerde göçmen seçmektedir. Pek tabii ki göçmenlerin hedef ülkeye geldikleri anda ihtiyaçların giderilmesi beklenemez. Hedeflenen üretkenlik artışı, yenilikçilik, büyüme, yoksullukla mücadele ve işgücü piyasasının açıklarının ortadan kaldırılması gibi faydaların elde edilmesi için dil ve teknik eğitimin yanı sıra sosyal ve kültürel desteklerin de sağlanması gereklidir, İkinci Dünya Savaşı sonrası göç alan Avrupa ülkelerinde uygulanan göç politikaları son yüzyılın en etkili örneğidir (Peri ve Sparber, 2009:69).

Tablo 2 'de, göç veren ülkeler için göçün ekonomik anlamda pozitif etkisi olarak işçi gelirleri işaret edilmiştir. Bu olguyu güçlendiren ve Dünya Bankası verilerine göre hazırlanan Grafik 1'de de göç alan ülkelerden, kaynak ülkelere yapılan göçmen (işçi geliri*) transfer akışının, günümüzde tahminen 700 milyar Amerikan Dolarına yaklaştığı, diğer finans kaynaklarına göre daha istikrarlı ve artış gösterir şekilde, sadece 2008 küresel kriz dönemi hariç, gerçekleştiği görülmektedir.

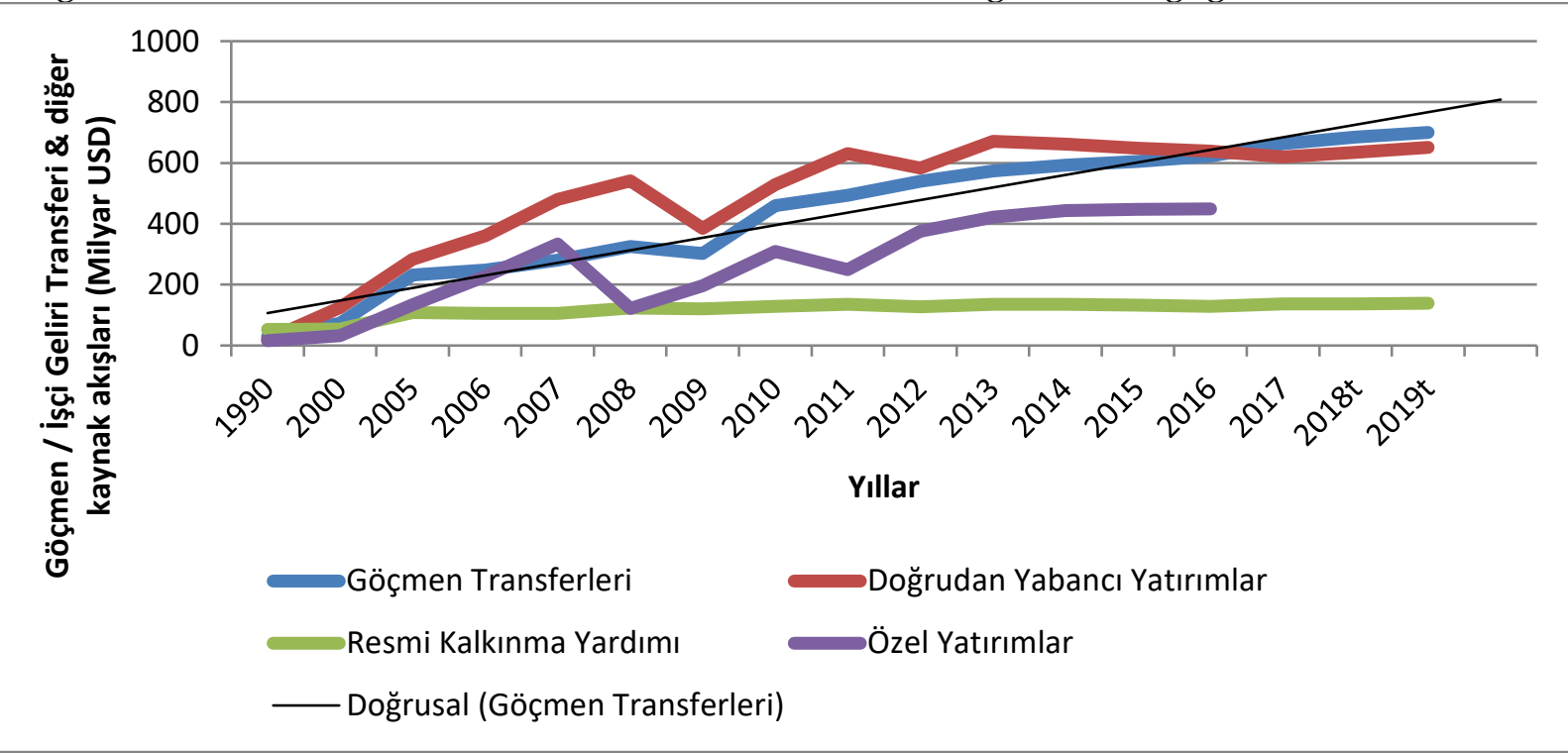

\section{Grafik 1. Göçmen (İşçi Geliri*) Transfer Akışının Diğer Kaynak Akışları ile Karşılaştırılması}

Kaynak: Dünya Bankası, 2018b verileri ile yazar tarafından oluşturulmuştur

Dünya Bankası, 2019, “Göç ve Beyin Göçü” raporuna göre, neredeyse her dönemde, göç eden bireylerin yatırımlarını ve tasarruflarını kaynak ülkeye gerek ardında bıraktığı yakınlarının ihtiyaçlarını karşılamak gerekse de milli duygular ile kendi ülkesinde değerlendirme arzusunda olduğu için aktardığı, göçün göç veren ülkenin kalkınması lehinde katkısı bulunduğunu belirtmektedir. Göçmen transferlerinin vardığı küresel boyut, literatürde yer alan pek çok çalışmaya konu olmuş ve özellikle gelişmekte olan ülkelerde yoksulluk aleyhindeki ektileri incelenmiştir (Adams ve Page:2003).

\section{Büyük Göçler, Nedenleri, Etkileri}

İnsanların yaşamaya alışkın oldukları toprakları, vatanlarını, bırakıp yeni alanlara göç etmelerinin altında sosyoekonomik, siyasal, sosyokültürel, güvenlik ve doğal şartlarda değişme başlıca nedenler olarak sayılmaktadır. Sayılan nedenlerin çoğu dünyada bilinen büyük göç hareketlerinin de kaynağıdır. 


\subsection{Kavimler Göçü}

4. yüzyıl; Çoğunluğu Türklerden oluşan kavimler Orta Asya'dan batıya doğru farklı göç yolları oluşturmuştur. Doğal nedenlerle verimsizleşen toprak, kuraklık, hastalıklar, ekonomik sıkıntı, Çin ve Moğol gibi yabancı kavimlerin baskısı sonucu Avrupa Kıtası'na kadar erişen kavimler yerleştikleri yeni mekanların çehresini değiştirmiş, yeni irklar ve siyasal yapılanmalar üzerinde etkili olmuştur.

\subsection{Amerika Kitasına Göç}

15. - 16. yüzyıl; Kristof Kolomb, Macellan ve Vasco da Gama seyahatleri sonucu dünyada her yer bilinir olmuştur. Amerika Kıtasının keşfi ile yeni dünyaya yaklaşık 60 milyon insan, macera, siyasal baskılardan uzaklaşmak, dinsel inançlarını özgürce yerine getirebilmek, kendilerine tanınmayan fırsatlardan faydalanabilmek gibi nedenlerle göç ederek yeni umutları yanlarında taşımıştır. Bu göçler, Avrupa ve dünya tarihinde dünden bugüne devam eden ekonomik ve siyasi etkiler beraberinde, araştırma, geliştirme ve bilim insanı yetiştirme konusunda sınırsız olanaklarla ABD'yi bilimsel ve teknolojik çalışmalarda lider konuma taşımıştır. Türkiye'den yaklaşık 8 bine yakın bilim insanının ABD'ye beyin göçü olarak yerleştiği bilinmektedir. Beyin avcısı ülkeler; ABD, Almanya, İngiltere, Kanada, Avusturalya, Fransa yetişmiş insan gücü üzerinde kaynak ve imkanlarını kullanarak halen beyin göçünü gerçekleştirmektedir.

\subsection{Avrupa'ya Göç}

İkinci Dünya Savaşı sonrası; Almanya, Belçika, Avusturya ve Fransa başta olmak üzere, ekonomisini yeniden yapılandırma arzusu ile kalkınma çabası başlatan Avrupa ülkelerinde genç nüfusun azalmış olması iş gücü ihtiyacı doğurmuş ve 1952' den sonra içlerinde Türkiye'nin de var olduğu Portekiz, İspanya, Yunanistan, İtalya, Fas, Tunus, Cezayir, Yugoslavya'dan işçi göçü başlamıştır. Diğer taraftan iyi eğitilmiş Alman Bilim adamları daha iyi araştırma ve çalışma olanakları nedeni ile ABD ve savaşa katılmayan ülkelere giderek beyin göçü gerçekleştirmişlerdir.

İşgücü göçü veren ülkelerde, hızlı ve kontrolsüz nüfus artışı, kırsalda yaşayanların istek ve ihtiyaçlarının çoğalması, gelir dağılımındaki dengesizlikler, istihdam sorunları, motivasyon ve yeni bir hayat beklentisi gibi nedenler, insanların göç kararı vermesinde tetikleyici olmuştur.

\subsection{Mübadele Göçü}

Mübadele yolu ile yapılan göçler, bir antlaşmanın esaslarına dayandırılarak ülke nüfuslarının karşılıklı olarak yer değiştirmesi, Türkiye tarihinde de yer almaktadır. Kurtuluş Savaşı sonrası Yunanistan ile yapılan anlaşmalar gereği ülkemizde yaşayan Rumlar ile Yunanistan'daki ve hatta sonrasında Baklanlarda yaşayan Türklerin arasında yer değiştirme göçleri yaşanmıştır. Bir diğer örnek, 20 Temmuz 1974 tarihinde başlayan Kıbrıs Barış Harekatı sonucu, Kıbrıs Adasında Türkler ve Rumlar arasında belirlenen yeni sınırlar halkların karşılıklı zorunlu göçüne neden olmuştur.

\subsection{Orta Doğu'dan Göç}

En sorunlu göç şekli olan, siyasal ve sosyoekonomik göç hareketi örneklerinden biri de Orta Doğu'da ortaya çıkan savaş, baskı, siyasi iradenin yarattığı sorunlar etkisiyle insanların vatanlarını terk etmek zorunda kalmalarıdır.

2.5.1. Sovyet Sosyalist Cumhuriyetler Birliği'nin Afganistan'a müdahalesi, 1979; ülkede istikrarsızlığa neden olmuş ve komşu ülkesi Pakistan'da 40 yıldan beri devam eden Afgan mülteci sorununu başlatmıştır. Pakistan tarafından paylaşılan verilere göre, ülkede yaklaşık 3 milyon Afgan yaşmakta olup, $\% 50$ si yasal olmayan yollardan ülkeye giriş yapmış ve kayıtsızdır (https://www.un.org/en/development/desa/population/migration/data/estimates2/estimates 19.asp/Erisim Tarihi:17.11.2020). Daha önce Sovyet Rusya'nın işgali yüzünden ülkelerini terk eden Afgan'lar, 2015 yılından itibaren de DAEŞ, Taliban tehdidi ile Avrupa'ya doğru düzensiz ve zorla göç yolculuğuna başlamışlardır. İran üzerinden yasal olmayan yollarla Türkiye giriş yapanların büyük çoğunluğu hedef olarak Avrupa ülkelerini seçmiş olsa da maalesef yolculukları Türkiye' de, sığınmacı ya da mülteci olarak sonlanmaktadır. Ortadoğu coğrafyasında devam eden savaşlar, siyasi istikrarsızlık, terör, çatışma ve güvenlik zafiyetleri, açlık, ve yoksullukla pekişince insanlar zorunlu göç etmek zorunda kalarak Türkiye'ye yönelik göç baskını oluşturmaktadırlar. Göç İdaresi 2020 yılı verilerine göre, kayıt altına alınan yaklaşık 298 bin Afgan, 145 bin Pakistanlı ve 143 bin İranlı mülteci ülkemizde yaşamaktadır. 
2.5.2. Körfez Savaşı, 1991; Kuzey Irak halkının bir bölümünün, Göç İdaresi 2020 yılı verilerine göre yaklaşık 600.000 bin kişinin, ülkemize göçü, savaş, baskı ve zulümden kaçan insan hareketliliğidir.

2.5.3. Suriye İç Savaşı, 2011; Esad rejiminin yarattığı güvensiz ortam ve ortaya çıkan iş savaş nedeni ile Suriye halkı ülkesinden göç etmek zorunda kalmıştır. Grafik 2' de görüleceği üzere, “Açık Sınır Politikası " çerçevesinde başlayan, hiç bir Suriyelinin geri çevrilmediği ilk mülteciden itibaren, Türkiye' de 2020 verileri ile kayıtlı 3,7 milyon Suriyeli mülteci yaşamaktadır.

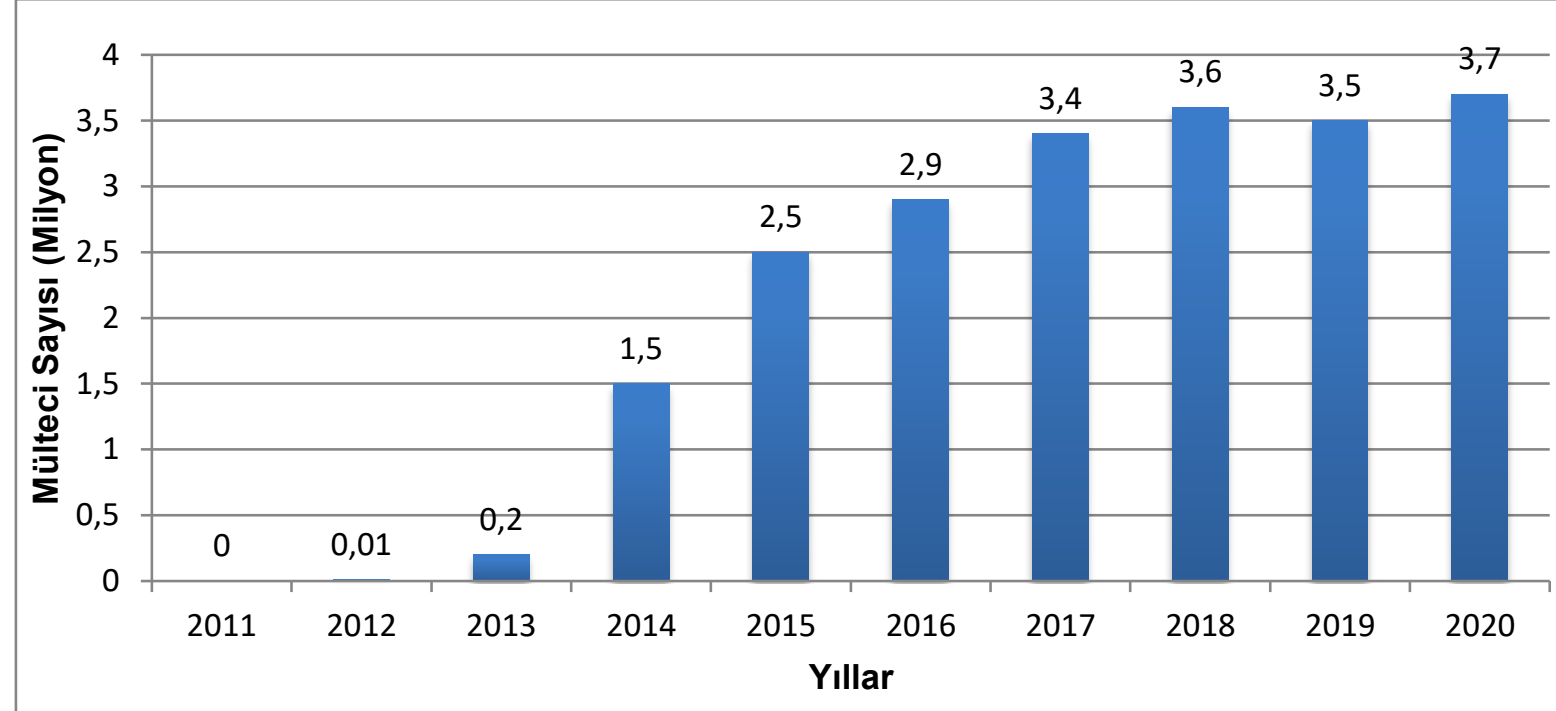

Grafik 2. Türkiye'deki Suriyeli Mülteci Sayısı (2011-2020)

Kaynak:https://www.un.org/en/development/desa/population/migration/data/estimates2/estimates19.asp verileri ile yazar tarafından oluşturulmuştur.

Türkiye, gerek sınır komşusu olması gerekse de uyguladığı göç politikaları nedeni ile diğer ülkelere göre daha fazla Suriyeli mültecinin hedef ülkesi haline gelmiştir. Grafik 3'de görüldüğü üzere, ülkesini terk etmek zorunda kalan yaklaşık 10 milyon Suriyelinin çoğunluğu Türkiye'de kalmak üzere, kendilerini kabul eden ülkelere ulaşmak üzere çaba göstermektedirler (Orhan ve Gündoğar, 2014:15). Avrupa ülkeleri başta olmak üzere, pek çok gelişmiş ülke göç politikaları ve göçmen kabul kriterlerine göre sınırlarını Suriyeli göçmenlere karşı kapalı tutmaktadır.

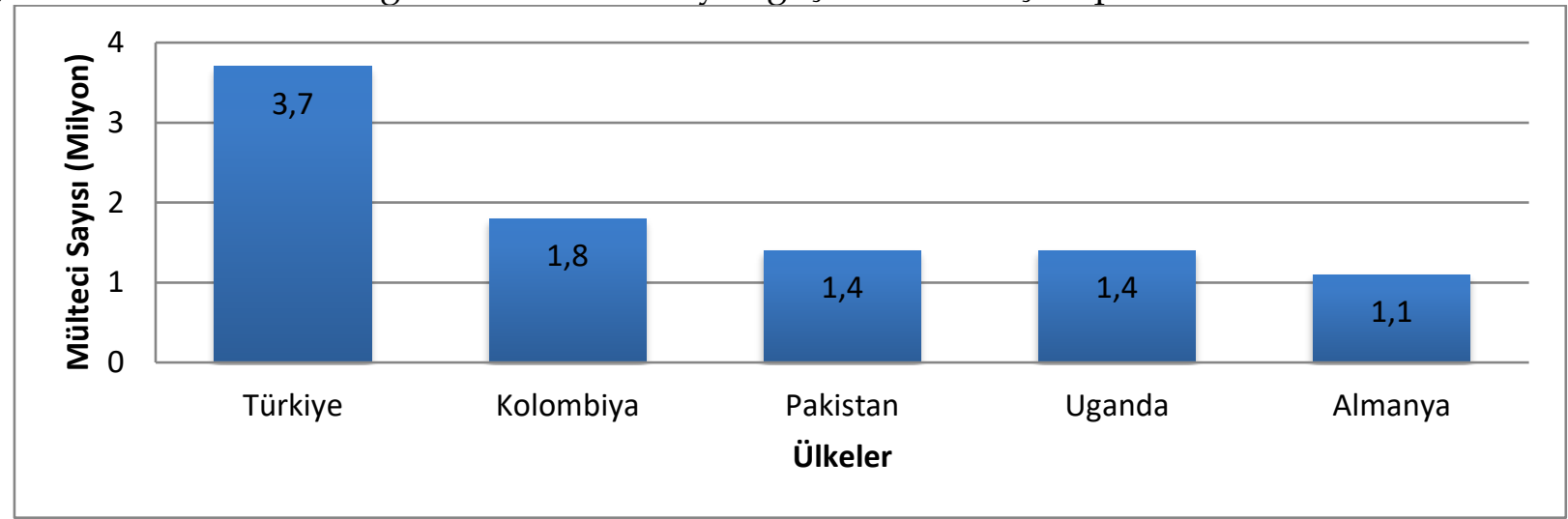

Grafik 3. Dünyada En Fazla Suriyeli Mülteci Ağırlayan Ülkeler

Kaynak: BM Mülteci Örgütü (UNHCR) Haziran 2020 verileri ile yazar tarafından oluşturulmuştur.

Sanayi Devrimi, İngiltere 1760-1830; itibaren gelişen teknoloji ve ulaştırma imkanları göç hareketinin başlamasına neden olmuştur. İkinci Dünya Savaşından itibaren ve özellikle son 20 yılda gelişen sosyal, ekonomik, siyasi olaylar ve güvenlik gibi farklı nedenlerle insanlar ülkelerinden ayrılarak başka ülkelere göç etmek zorunda bırakılmış ya da tercih kullanmıştır. Dünya nüfusunun büyük çoğunluğu doğduğu ülkede yaşaminı sürdürüyor olsa bile Birleşmiş Milletler nüfus istatistiklerine göre, Grafik 4. ve 5.'de 2020 yılı itibarı ile yaklaşık 8 milyar insanın 272 milyonu (\%3,5) 
bulundukları yere kıyasla daha güvenli bir ortamda hayat sürdürmek, gelecek nesillerine konforlu bir ortam hazırlamak, eğitim görmek, çalışmak ya da emekliliğini geçirmek gibi nedenlerle çoğunlukla gelişmiş ülkelere göç edebilmektedir.

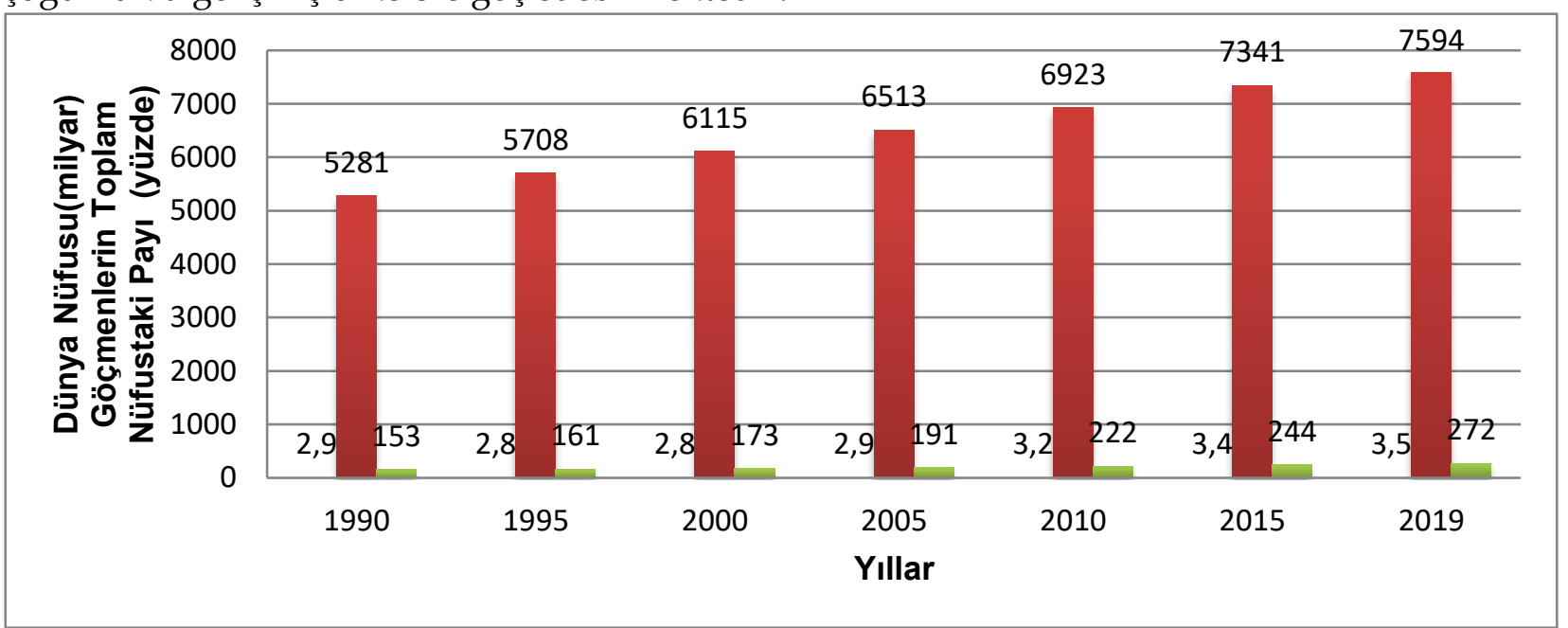

Grafik 4. Dünyadaki Göçmen Sayısı, Toplam Nüfusa Oranı (1990-2019)

Kaynak:https://www.un.org/en/development/desa/population/migration/data/estimates2/estimates19.asp verileri ile yazar tarafından oluşturulmuştur.

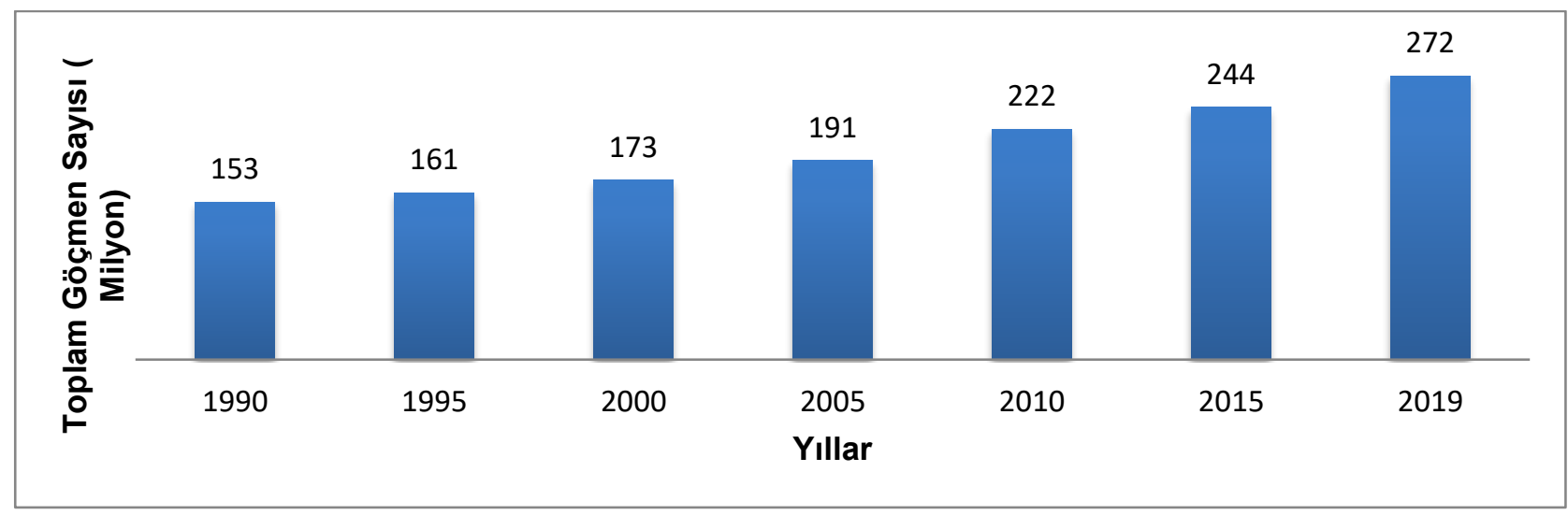

Grafik 5. Dünyadaki Göçmen Sayısı (1990-2019)

Kaynak:https://www.un.org/en/development/desa/population/migration/data/estimates2/estimates19.asp verileri ile yazar tarafından oluşturulmuştur

Göçün nedenleri arasında da sıralandığı gibi daha iyi yaşam koşulları, istihdam olanakları, yüksek ücret seviyesi, aile bireyleri için sağlanacak eğitim ve gelecek kaygıları ile gerçekleşen göç, göçmeni hayallerini gerçekleştirebileceğine inandığ1 bölgeye yönlendirmektedir. Tablo 3 ve $4^{\prime}$ de, (MPI, 2019), nüfusu 100.000 kişinin altındaki ülkelerin hariç tutulduğu çalışmaya göre özellikle gelişmiş bölge ve ülkeler göçmenler açısından daha çok tercih edilip seçilmektedir.

Tablo 3. Uluslararası Göçmen Stoku, 1990-2019 (Milyon Kişi)

\begin{tabular}{|c|c|c|c|c|c|c|c|}
\hline Göçmenlerin Varış Bölgesi & 1990 & 1995 & 2000 & 2005 & 2010 & 2015 & 2019 \\
\hline Gelişmiş Bölgeler & 82,4 & 92,3 & 103,4 & 117,2 & 132,6 & 140,5 & 152,3 \\
\hline Gelişmekte olan Bölgeler & 70,2 & 68,5 & 69,3 & 74,1 & 89,2 & 103,2 & 119,7 \\
\hline Avrupa & 49,2 & 52,8 & 56,3 & 64,1 & 72,4 & 76,2 & 81,3 \\
\hline Asya & 48,1 & 46,6 & 49,3 & 53,4 & 65,9 & 75,1 & 79,1 \\
\hline Afrika & 15,7 & 16,3 & 14,8 & 15,2 & 16,8 & 20,7 & 21 \\
\hline Dünya & 152,6 & 160,8 & 172,7 & 191,3 & 221,8 & 243,7 & 272 \\
\hline
\end{tabular}

Kaynak:https://www.un.org/en/development/desa/population/migration/data/estimates2/estimates19.asp verileri ile yazar tarafından oluşturulmuştur. 
Tablo 4. Uluslararası Göçmen Nüfusu, Ülkelerin Toplam Nüfusu İçinde Göçmenlerin Payı, Varış Noktasındaki İlk 25 Ülke, 2019.

\begin{tabular}{|c|c|c|c|c|}
\hline Sira & $\begin{array}{l}\text { Varış noktasındaki } \\
\text { (göç alan) ülke }\end{array}$ & $\begin{array}{l}\text { Toplam Ülke Nüfusu } \\
\text { ( milyon kişi) }\end{array}$ & $\begin{array}{c}\text { Toplam Göçmen } \\
\text { Sayısı (milyon kişi) }\end{array}$ & $\begin{array}{c}\text { Göçmenlerin Nüfus içindeki } \\
\text { Payı ( \%) }\end{array}$ \\
\hline 1 & $\mathrm{ABD}$ & 329 & 51 & 15 \\
\hline 2 & Almanya & 84 & 13 & 16 \\
\hline 3 & Suudi Arabistan & 34 & 13 & 38 \\
\hline 4 & Rusya & 146 & 12 & 8 \\
\hline 5 & İngiltere & 68 & 10 & 14 \\
\hline 6 & Birleşik Arap Emirlikleri & 10 & 9 & 90 \\
\hline 7 & Fransa & 65 & 8 & 13 \\
\hline 8 & Kanada & 37 & 8 & 21 \\
\hline 9 & Avusturalya & 25 & 7,5 & 30 \\
\hline 10 & İtalya & 61 & 6,2 & 10 \\
\hline 11 & İspanya & 47 & 6,1 & 13 \\
\hline 12 & Türkiye & 83 & 5,9 & 7 \\
\hline 13 & Hindistan & 1,366 & 5 & 0 \\
\hline 14 & Ukrayna & 44 & 5 & 11 \\
\hline 15 & Güney Afrika & 59 & 4,2 & 7 \\
\hline 16 & Kazakistan & 19 & 3,7 & 20 \\
\hline 17 & Tayland & 70 & 3,6 & 5 \\
\hline 18 & Malezya & 32 & 3,4 & 11 \\
\hline 19 & Ürdün & 10 & 3,3 & 33 \\
\hline 20 & Pakistan & 216,5 & 3,2 & 2 \\
\hline 21 & Kuveyt & 4,2 & 3 & 72 \\
\hline 22 & Çin, Hong Kong & 7,4 & 2,6 & 40 \\
\hline 23 & Iran & 83 & 2,6 & 3 \\
\hline 24 & İsviçre & 8,5 & 2,5 & 30 \\
\hline 25 & Fildişi Sahili & 25 & 2,5 & 10 \\
\hline
\end{tabular}

Kaynak: https://www.migrationpolicy.org/programs/migration-data-hub verileri ile yazar tarafından oluşturulmuştur.

Göçlerin yönüne baktığımızda, en çok göç alan ABD, Suudi Arabistan, Almanya, Rusya, BAE, İngiltere, Fransa, Kanada ve Avusturalya gibi gelişmiş bölgelerdeki, ekonomik fırsatların, iş olanaklarının ve ücretlerin yüksek olduğu ülkelerdir (World Bank, 2019a).

Dünya nüfusunda göçmen oranı yüzde $3.5^{\prime}$ luk bir paya sahipken bu oran zorunlu göç sonucu Türkiye'ye ulaşan, uluslararası hukuka uygun şekilde geçici koruma sağlanan Suriyeliler sayesinde ülkemizde, Grafik 6'da görüldügü üzere yüzde 7'dir ve tarihin en büyük sorunlarından bir olan sığınmacı sorunu ile sosyal, siyasi, güvenlik ve ekonomik alanlarda baş başa kalınmıştır.

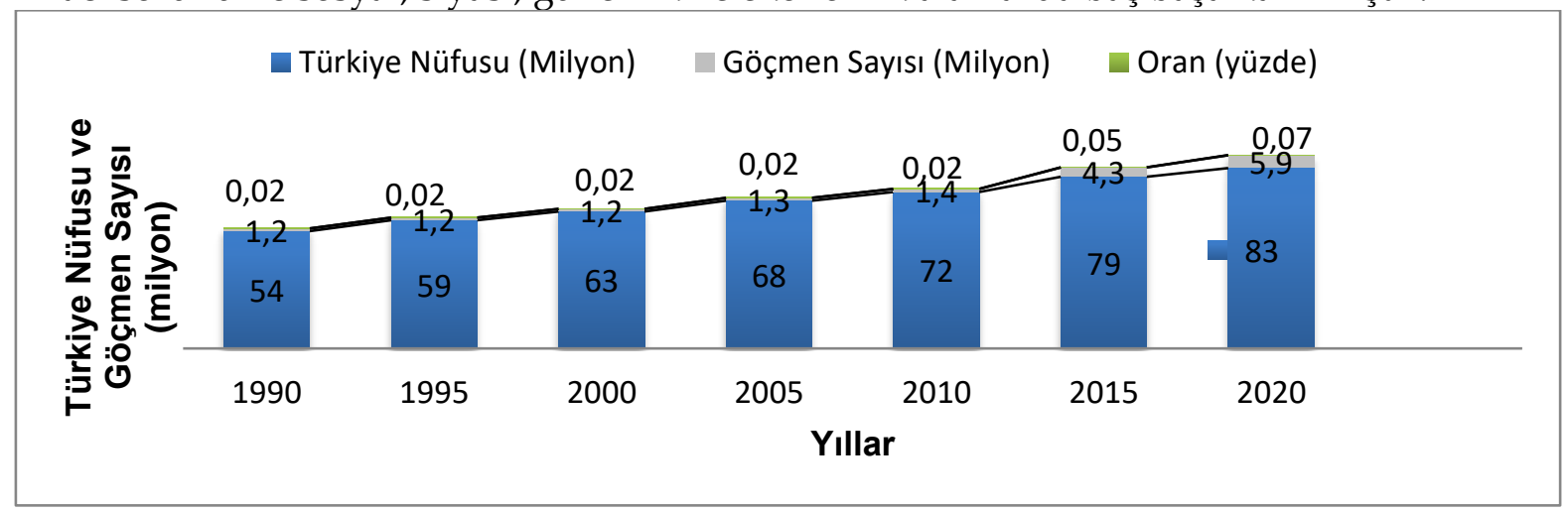

Grafik 6. Türkiye'deki Göçmen Sayısının Toplam Nüfusa Oranı( 1990-2019)

Kaynak: http://migrationpolicy.org/programs/data-hub verileri ile yazar tarafından oluşturulmuştur.

Yabancıların bazıları, uluslararası anlaşmalarla sağlanan vize muafiyetleri ya da 3 ay süreyle geçici ikamet edebildikleri ülkemizde ikamet izni alarak yasal olmayan şekilde çalışabilmektedir. 
Tablo 5. 2016 yılında Türkiye'de ikamet izni, mülteci/sığınmacı statüde bulunan yabancılar (1000 x kişi)

\begin{tabular}{|c|c|c|}
\hline Uyruk Ad1 & İkamet İzinli & Mülteci/ Sı̆̈ınmac1 \\
\hline Irak & 55,983 & 592,128 \\
\hline Suriye & 48,738 & $2,900,030$ \\
\hline Azerbaycan & 39,184 & 138,723 \\
\hline Türkmenistan & 24,253 & 297,513 \\
\hline Rusya Federasyonu & 21,006 & \\
\hline Afganistan & 20,148 & 143,864 \\
\hline Gürcistan & 18,511 & \\
\hline Özbekistan & 18,270 & 145,012 \\
\hline İran & 16,000 & 261,317 \\
\hline Ukrayna & 14,031 & $4,478,587$ \\
\hline Pakistan & 13,025 & \\
\hline Dĭğer & 185,093 & \\
\hline Toplam & 474,242 & \\
\hline
\end{tabular}

Kaynak: T.C. İçişleri Bakanlığı, Göç İdaresi Genel Müdürlüğü, 2016 Türkiye Göç Raporu, www.goc.gov.tr

\section{Göç Yönetimi}

Dünya genelinde son yıllarda yaşanmakta olan göç hareketliliği, ülkelerin dinamik bir şekilde değişim ve gelişim içinde olmasını, çoğu zaman da karmaşa ile baş etmesini gerektirmektedir. Bir ülkenin gelişiminin yanı sıra geleceği için göç hareketleri ve yönetimi, ekonomik, siyasal, sosyal ve beşeri unsurlar yönünden ele alınmalıdır. Göç yönetimi, göç eden kişilerin hedef ya da transit ülkeye girmeden önce, ortaya çıkabilecek muhtemel sorunlarla karşılaşmamak ya da giriş yapılan ülke tarafından göçün kargaşa yaratmadan yönetilebilmesi için birçok kriter, kural, uygulama ve hukuki düzenlemeler ile başlamaktadır.

\subsection{Ekonomik Göç Yönetimi}

Göç hareketi ister zorunlu ister gönüllü olsun, ülkelerin önemli ekonomik sorunlarla karşılaşmasına ve mücadele sürecine girmesine neden olmaktadır (Demirhan ve Aslan, 2015:29). Göç hareketlerinin ekonomik unsurlar açısından yönetiliyor olması; bireylerin, toplumların var olan istikrarı, ekonomik koşulları, birikimleri ve düzenlerinde ülkelerine gelen göçmenler nedeni ile bir bozulma olmamasını sağlamak olmalıdır (Akıncı, vd., 2015:59). Göç yönetimi politikalarından beklenen, ülkeden göç verme durumunda sağlanan girdiler ile kalkınma ve ekonomik büyümeyi desteklemektir. Ancak, ülkeye göç alma durumunun süreklilik göstermesi halinde ise istenmeyen bir durum oluşmaktadır. Ülkeler sürekli göç aldıklarında ülke ekonomisinde görülen bozulmalar, artan ucuz iş gücü dolayısı ile azalan istihdam, işsizlik, milli gelirde azalma gibi sorunlar yaşanmakta, kronikleşmekte ve ülke ekonomisinde makro sorunlar beraberinde bozulmalar meydana gelmektedir. Göç yönetimi ve politikaları ile olumlu etkiler sağlanması beklenen büyüme, yatırım, beşeri sermaye, bilgi, teknoloji ve refah düzeyinin arttırılması gibi konular göç hareketlerinde önem arz etmektedir. Ülkeler, her iki yönüyle de göç hareketini, gelecek nesillerin beklentilerini de karşılayacak şekilde analiz edilmiş bir politika ile yönetmelidir.

\subsection{Siyasal Göç Yönetimi}

Dünyada hızla çoğalan etnik ayrımcılık, siyasi istikrarsızlık, çatışma ve savaşlar, demokrasiden uzaklaşan yönetimler, sayısı neredeyse 300 milyona yaklaşan insanın göç hareketine katılmasına neden olmaktadır. Bu durum göç alan ve göç veren ülkelerin uluslararası standartları içeren, siyasi anlamda göç yönetimi yapıyor olmasını gerektirmektedir. Göç hareketlerinin siyasi ve güvenlik unsurlar açısından yönetiliyor olması; göçmen ve sığınmacılara verilen hakların yasal düzenlemelerden geçirilmiş, ulusal kamu düzeninde olumlu karşılanacak demokratik yurttaşlık haklarının belirlenmiş ve göçmen kabul eden ülkelerin de bu düzenlemelere uyuyor olması beklenmektedir.

\subsection{Sosyal ve Beşeri Unsurlar Yönünden Göç Yönetimi}

Entegrasyon, göç politikası oluşturmuş ve göç yönetimi yapan ülkelerin sosyal ve beşeri yapısındaki en önemli özelliktir. Göç alan ülkenin, toplum yapısında bir farklılaşma ve karmaşa yaratmamak adına göç eden bireylerin ulusal - yerel toplumla uyumlanma süreci yürütmekle 
sorumlu olduğu bir konudur. Göç eden kişiler hem göç ettikleri ülkenin kültüründen etkilenir hem de kendi kültürlerini göç ettikleri alana taşıma arzusu güttüğü için kültür etkileşimi gerçekleşir. Göç hareketlerinden sonra ortaya çıkan bütünleşme, asimilasyon ve ayrışma gibi evreler entegrasyon yönetimini gerçekleştiren ülke tarafından ilerleyen zaman içinde farklı sorunlarla karşılaşmamak adına dikkate alınmalıdır (Tunç, 2015:44-45).

\subsection{Türkiye' de Göç Yönetimi ve Entegrasyon}

Göçün siyasi ve idari organlar tarafından düzenlenmesi ve yönetilmesi gerekliliği Türkiye'de göç yönetim politikası olarak Cumhuriyet ile birlikte oluşturulmuştur. 1923'te oluşturulan, Türk kültür ve ırkına öncelik tanıyan, yabancısız kurgulanan göç yönetim politikası uygulamaya konulmuştur. Türkiye, kuruluşun ilk yıllarında nüfus mübadelesi ve soydaş göçü ile nüfusunu büyük ölçüde yenilemiştir. İkinci Dünya Savaşı sonrası Avrupa'ya işçi göçü vermiş, Avrupa Birliği üyelik sorunları sürecinde gerçekleştirdiği uyum çalışmaları etkisi ile sığınmacı ve göçmenler ile ilgili olarak politika ve uygulamalarında değişiklikler yapmıştır. Küresel insan hareketliliği ve göç dalgaları ile "göç alan”, "göç veren” ve "transit- göç geçiş ülkesi” olmuştur. Türkiye Göç Yönetim Politikası ve bileşenleri Tablo 6.' da sınıflandırıldığı gibi, günümüze kadar beş faktörden etkilenerek gelişim ve değişim göstermiştir.

Tablo 6. Türkiye Göç Yönetim Politikası Bileşenleri

\begin{tabular}{|c|c|c|c|}
\hline Faktör/Dönem & Yöntem & Gelişim & Değişim \\
\hline 1923-1960 & $\begin{array}{l}\text { Ulus-devlet, milli } \\
\text { kimlik aidiyet } \\
\text { oluşturma }\end{array}$ & $\begin{array}{l}\text { Türk soyu ve kültürü } \\
\text { taşıyan kişiler ülkeye } \\
\text { yerleştirilir. }\end{array}$ & $\begin{array}{l}1934 \text { İskân Kanunu; Türkiye'ye göç } \\
\text { hakk1 sadece Türk soyundan meskûn } \\
\text { ve göçebe kişilere verilir. }\end{array}$ \\
\hline NATO Üyeliği & $\begin{array}{c}\text { Uluslararası standart ve } \\
\text { sözleşmelerle ortak } \\
\text { hareket ve güvenlik } \\
\text { önlemleri }\end{array}$ & Güvenlik esaslıdır. & $\begin{array}{l}\text { Sosyal, siyasal, ekonomik açıdan } \\
\text { stratejiler geliştirilmiştir. }\end{array}$ \\
\hline $\begin{array}{l}\text { Cenevre } \\
\text { Sözleşmesi }\end{array}$ & $\begin{array}{c}\text { Uluslararası } \\
\text { sözleşmelerle } \\
\text { (çekinceli) ortak } \\
\text { hareket ve güvenlik } \\
\text { önlemleri } \\
\end{array}$ & $\begin{array}{l}\text { Mülteci kabulü; ırk, dil, din } \\
\text { veya ülke ayrımı } \\
\text { yapmadan, }\end{array}$ & $\begin{array}{l}\text { Sosyal, siyasal, ekonomik açıdan } \\
\text { stratejiler geliştirilmiştir. }\end{array}$ \\
\hline $\begin{array}{l}\text { AB Üyelik } \\
\text { Sorunları }\end{array}$ & $\begin{array}{l}\text { Uluslararası } \\
\text { sözleşmeye göre, göç } \\
\text { alan, göç veren ve } \\
\text { transit ülke statüsü ile } \\
\text { konumlandırılmıştır. }\end{array}$ & $\begin{array}{l}\text { AB ile ilişkilerde Türkiye, } \\
\text { uyum süreçleri } \\
\text { kapsamında göç rejimi de } \\
\text { farklılaşmıştır. }\end{array}$ & $\begin{array}{l}1990 \text { dan itibaren, Uluslararası göç } \\
\text { hareketlerinde taraf olmaktadır. }\end{array}$ \\
\hline $\begin{array}{l}2011 \text { Suriye İç } \\
\text { Savaş1 }\end{array}$ & $\begin{array}{l}\text { Açık sınır politikası ile } \\
\text { Türkiye'de uluslararası } \\
\text { koruma altına alınan } \\
\text { mülteciler. }\end{array}$ & $\begin{array}{c}11 \text { Nisan } \\
2013 \text { tarihinde yürürlüğe } \\
\text { giren } 6458 \text { sayılı Yabancılar } \\
\text { ve Uluslararası Koruma } \\
\text { Kanunu, eksiklikleri } \\
\text { gidermek ve gelişim için } \\
\text { atılan önemli bir adımdır. }\end{array}$ & Yaklaşık 3,7 milyon mülteci.... \\
\hline
\end{tabular}

Kaynak : Örselli, E. ve Babahanoğlu,V. “ Türkiye'nin Göç Yönetimi ve Göçmen Politikalarının Gelişimi: Bir Kamu Politikası Analizi “ Uluslararası Sosyal Araştırmalar Dergisi , Cilt 9, sayı 43 s. 2065, 2016, verileri ile yazar tarafından oluşturulmuştur.

Anadolu tarihi bir yönüyle göçler tarihidir ve Türkiye' deki hemen her birey ve toplumsal kesim ile hemen her mekanın üzerine sinmiş bir göç etkisi vardır. Türkiye, jeopolitik konumu nedeni ile hem çok değerli hem de çok sorunlu bir noktada bulunmaktadır. Son 10 yılda, Suriye ile sinır komşusu olması, insanların ülkelerinde can güvenliği kalmaması nedeni ile açık sınır politikası başlatan ve göçün en tehlikeli çeşidi olan siyasi ve güvenlik sorunlarının oluşturduğu Orta Doğu kaynaklı kitlesel göç ile karşı karşıya kalmıştır. Diğer taraftan, Türkiye'yi artan bir hızla hedef alan, düzenli göç dalgalarından biri, "uluslararası emekli göçü", Antalya, Aydın, Muğla gibi illerimizde varlığını hissettirir şekilde Avrupalı emeklilerin oluşturduğu, gerek ekonomik gerekse de iklim avantajları nedeni ile gerçekleşen göç dalgasıdır.

Göçün ülkeler açısından oluşturduğu ekonomik sorunların ardından, vatandaşların güvenliği, ülkenin asayiş ve güvenliği gelmektedir. Göç, çoğu zaman toplumsal ve kamu düzenine ya da ulusal 
kimliğe karşı bir tehdit olarak görülebilmekte ve/ veya tehdit oluşturabilmektedir. Türkiye, göçmen ve mültecilerin sağlık ve kayıt sorunları, eğitim, dil öğrenme, sosyal ve kültürel imkanlardan faydalandırma gibi konularda en az sorunla ilerleyebilmek için yeni politika ve stratejiler geliştirmektedir. Özellikle 1980 sonrasında, göçün ekonomik ve demografik boyutuna güvenlik temelli bakış açısı getirmiş ve göçmenlerin ülkeye girişleri, ikamet, çalışma izni almaları ve vatandaşlık hakkı edinebilmelerini ilgili yasalar çerçevesinde düzenlemiştir (Ökmen, 2010:1415).Ancak, özellikle 2011 yılından itibaren yoğun bir şekilde Türkiye'ye sığınan Suriyeliler arasında pek çok terör örgütü üyesinin bulunduğu , yaşam koşullarındaki güçlükler nedeni ile suça karışma oranlarının yüksekliği emniyet güçlerinin yoğun ve dikkatli çalışmaları sonucunda ortaya konmaktadır (Erdoğan, 2015).

\section{Sonuç ve Değerlendirme}

Göç yapan insan yanında bavulunu taşırken anılarını arkasında bırakır. İmkanlarının ve umutlarının bittiği yerde göçü ve maalesef gittiği yerde imkan bulamayınca da suçu başlar. Bu durum sosyal bütünleşme ve entegrasyonun ne kadar önemli olduğunu, hem küresel hem de devletler ölçeğinde rasyonel politikaların oluşturulması gerektiğini göstermektedir. Göçü bir sorun olarak görmekten ziyade göçün oluşturduğu ekonomik, toplumsal sonuçlarını öngörebilmek, gerekli altyapıyı oluşturup süreci kontrol altına alabilmek önemlidir. Eğitim, sağlık, güvenlik, toplumsal dayanışma, toplumsal kabul mekanizmalarını çalıştıracak politikaların üretilmesi ve güncellenmesi gerekmektedir.

Göç nedeni, şekli, çeşidi ve etkisi ne olursa olsun şiddetli bir artışla devam etmekte, birey ve toplumların hayatını derinden etkilemektedir. Göçmenler gittikleri yerde iki temel güdüyle hareket ederler. Birincisi iyi bir iş sahibi olabilmek, diğeri ise gittikleri ülkenin kaynak ve şartlarından faydalanırken kendi etnik grubundan ayrılmadan uyum sağlayabilmek. Göçün öznesi insan olduğuna göre yerleştiği yere uyum sağlayamadığı takdirde göç eylemini tamamlamış sayılmayacaktır.

Gelişmiş ve yüksek gelirli ülkelere yapılan göçler, göçmen transferlerinin kaynağını oluşturmaktadır. Bu transferler pek çok kırsal haneye gıda sağlanmasında rol oynadığ gibi ekonomisi zayıf yoksul ülkeler için sağlık, gıda, eğitim gibi öncelikli alanlarda sigorta olmakla birlikte zaman içinde ülkelere yoksulluğun azaltılması, yatırım ve kalkınma hamlelerine finansman desteğidir.

Kapsamlı hazırlanan, uluslararası sözleşmeleri içeren göç politikaları iyi yönetilecek süreçleri de içinde barındırır. Ev sahibi ülkenin, göçü kapsayıcı ve kurumsal bir sistem ile karşılayabilmesi, göçmen ve mültecileri sermaye, yetenek, beceri gibi özelliklerine ve uzun dönemde ekonomik büyümeye katkı sağlayacak şekilde konumlandırması güçlü göç politikalarının sonucudur. Gelişmiş ve gelişmekte olan ülkeler için göçmen işçiler ulusal ekonominin kalkınmasında rol oynarken, göç, göç literatüründe kendine yer bulan, uluslararası bilimsel göç çalışmalarında sıkça rastlanan, "Çiçeklerle karşılanan işçilerden, istenmeyen yabancılara dönüşmek" sloganı gerçekliğini korumaya devam edecektir.

Göç alan ülkelerin toplumsal ve kültürel sorunlar ile yüzleşmesinin yanında ağırlıklı olarak siyasal, güvenlik, sağlık, beslenme ve ekonomik yapıda tıkanıklıklar, yük artışları gibi problemler görülmektedir. Göç veren ülkede ise nüfusun azalmasıyla birlikte, emek yoğun iş kollarında boşluklar, tek tip sosyal ve kültürel hayat, doğum oranlarında azalma izlenmektedir.

Türkiye, kuruluşundan bu yana büyük göç dalgaları ile karşılaşmış olmasına rağmen, her zaman ve her koşulda, özellikle Suriyeli mülteci ve sığınmacılara karşı, kendi vatandaşlarına sağladığı imkan ve hakları sunmaktan çekinmemiş, ciddi miktarda kaynak kullanarak kamu harcamalarının artmasına ek olarak güvenlik ve sosyal yaşamda da ağır tahribatlarla karşı karşıya kalmıştır. Diğer taraftan, sömürgeciliğe ve köle ticaretine alışkın, çoğu gelişmiş ve pek çok Batı Avrupa Ülkesi kitlesel göçe karşı "ulusal çıkarlar esastır" politikası ile katı ve yasakçı bir tutum izlemiştir.

Risk ve fırsatların iç içe geçtiğinin altını çizerek, uluslararası göçün yenilik, sermaye birikimi, beşeri sermaye, diş ticaret ve iç talep gibi çeşitli kanallar yoluyla göç alan ülkelerde ekonomik 
büyümeyi desteklediğine dair veriler bulunmaktadır. Konut satışları, inşaat sektöründe canlanma yaratmaktadır. Kira artışları, yerel halk için ev bulma sıkıntısı oluştururken, bazı semtlerde yabancılar tarafından kümeleşmeler meydana gelmektedir. Küçük işletmelerde kaçak işçi çalıştırılması ya da yerel haklın çalışmak istemediği işlerde mültecilerin çalışması istihdam sorununu oluşturduğu iddia edilmesine rağmen vasıfsız iş gücüne olan ihtiyaç azalmakta ve işletme için maliyetlerde düşüş kaydedilmesine rağmen vergi kaybına ve kayıt dışı istihdam sorununa yol açmaktadır.

Güvenlik ve asayiş ile ilgili sorunlar gündemde tutulması ve dikkatle izlenmesi gereken konulardır. Sınır illerinde ve büyük kentlerde meydana gelen mülteci yığılması, sağlık ve belediye hizmetlerinde aksama ve yetersizliğe neden olmakta beraber ek kapasite ve bütçeye ihtiyaç yaratmaktadir.

Göç ettiği ülkede kalmaya devam eden yabancılar için güvenli yasal haklara, istihdam sözleşmelerine, mesleklerine ve sektörlerine bağlı oturma hakkı, çocuklarına eğitim fırsatı, sosyal haklar sağlandığı sürece düzgün ekonomik ve sosyal entegrasyon sağlanabilecektir.

Ekonomik, siyasal, sosyal, eğitim, demokrasi ve vicdani alanlarda güçlü sayılan ülkelerin göçmen yükü ile karşılaşmamak, hedef ülke konumunda kalmamak için çeşitli önlemler almaları gerekmektedir. Özellikle, kaynak ülkelerde oluşan ekonomik sorunları ortadan kaldıracak eylemlerin yanında siyasi sorunlara, barış̧̧ı çabalar sunmaları ve insan haklarına destek vermeleri beklenmelidir.

\section{Kaynakça}

Adams, R.H., \& Page, J. (2003). The impact of international migration and remittances on poverty in developing countries, Washington, DC: World Bank Policy Research Working Paper.

Akıncı, B., Nergiz, A. ve Gedik, E. (2015). Uyum süreci üzerine bir değerlendirme; göç ve toplumsal kabul, Göç Araştırmaları Dergisi, (1)2, 58-83.

Barkın, E. (2014). 1951 tarihli mülteciliğin önlenmesi sözleşmesi, Ankara Barosu Dergisi, 72(1),333- 360.

Birleşmiş Milletler Yüksek Komiserliği ve İçişleri Bakanlığı, (2005). İltica ve göç mevzuatı, Ankara :BM Mülteciler Yüksek Komiserliği ve İçişleri Bakanlığı Yayını.

Boudon R., Besnard, P. \& Cherkaoui, M. (1989). Dictionnaire de la Sociologie, Larousse, Paris:153.

Demirhan, Y., ve Aslan, S. (2015). Türkiye'nin sınır ötesi göç politikaları ve göç yönetimi, Birey ve Toplum Sosyal Bilimler Dergisi, 5(1), 23-62.

Erdoğan, M. (2015). Türkiye'deki Suriyeliler: Toplumsal kabul ve uyum araştırması, Göç Çalışmaları Dizisi, İstanbul Bilgi Üniversitesi Yayınları, 279.

Gilles F. (2002). La Dictionnaire de Sociologie, Armand Colin: Paris,157.

Göç İdaresi Genel Müdürlüğü (2015). Göç, Göç Tarihi : Göç İdaresi, Göç ile İlgili Uluslararası Kuruluşlar: Ankara.

Gresle F., Parrof M., Perin M. \& Triper P. (2000). Dictionnaire des Sciences Humaines, Sociologie/Antropologie, Avusturalya: Nathan Universite Collection , 238.

İçduygu, A. ve Sirkeci, İ. (1999). Cumhuriyet dönemi Türkiye'sinde göç hareketleri, 75 yılda köyden kentlere, Oya Baydar ( der), İstanbul Tarih Vakfı Yayınları, 250.

Kane, H. (1995). Leaving Home, Society , (12)4, 16.

Keleş, R. (1996). Kentleşme Politikaları, İmge Yayınevi , 752.

Kofman E. (1999). Female 'Birds of Passage' a decade later: gender and immigration in european union, International Migration Review , 33(2), 108-179.

Li, M., \& Frieze, I.H. (2012). Before the big decision: Psycological theories on premigration motivation, immigration policies, challenges and impact, Nova Science Publishers, 3-27.

Murat, S., ve Taşkesenlioğlu, Z. (2009). Avrupa Birliği düzeyinde göç, entegrasyon ve yerel yönetimler, Zeytinburnu Belediyesi Kültür Yayınları, 14.

Ökmen, Ö. (2010). Yabancılar hukukunda göçmenler, Yayımlanmamış Yüksel Lisans Tezi, Gazi Üniversitesi, 178.

Orhan, O., ve Gündoğar, S.S. (2015). Suriyeli sığınmacıların Türkiye'ye etkileri, ORSAM Yayını, Rapor No: 195. 
Örselli, E., ve Babahanoğlu,V. (2016). Türkiye'nin göç yönetimi ve göçmen politikalarının gelişimi: Bir kamu politikası analizi , Uluslararası Sosyal Araştırmalar Dergisi , 9(43) 2063-72.

Peri, G., \& Sparber,C. (2009). Task specialization, immigration, and wages, American Economic Journal: Applied Economics 1(3),135-169.

Sencer, Y. (1979). Tü̈kiye'de kentleşme, Kuiltü̈ BakanlığıYayınları 345(12), 28.

Tunç, A. Ş. (2015). Mülteci davranışı ve toplumsal etkileri: Türkiye'deki suriyelilere ilişkin bir değerlendirme, Tesam Akademi Dergisi, 2(2), 29-63.

Ziya, O., (2012). Mülteci-göçmen belirsizliğinde iklim mültecileri, TBB Dergisi, 99, 229-240.

http:/ / documents1.worldbank.org/curated/en/551261580801381893/pdf/Migrationand-Brain-Drain.pdf , 18.11.2020

http://www.migrationpolicy.org/programs/data-hub/charts/top-25-destinations-internationalmigrants,13.09.2020

https:// www.resmigazete.gov.tr/arsiv/10898.pdf, 15.10.2020

https:/ / www.tuik.gov.tr ,13.12.2020

https:// www.un.org/en/development/desa/population/migration/data/estimates2/es timates19.asp , 17.11.2020

\section{Aim and Scope}

\section{Extended Abstract}

The Subject, The Management and Integration Of International Migration, Sampling of Turkey, has been examined in three sections. First, conceptual presentations are presented with the causes and effects of migration, while, the major migrations known in the world are examined with their global reflections in the seconf part. For centuries, threats of immigration on countries, effects on political structures, ecomomies, demographic and cultural structures as well as the gains through the management and integration of migration, the sampling of Turkey, has been examined on the third part. What the effects of refugee, integration are on the economy of the host country, what alterations it would make in short and long term, how it would be transformed into something beneficial rather than a burden on the economy of the country, are presented with migration management and policy recommendations.

While the migrant person carries his luggage with him, he leaves his memories behind. When his possibilities and hopes are over, his immigration starts and, unfortunately, when he cannot catch his possibilities and hopes at the place where he goes, his crime begins.

Social cohesion and integration is very important and also it is necessary to establish rational policies both globally and at the scale of the states. Rather than seeing migration as a problem, it is important to foresee the economic and social consequences of migration, to create the necessary infrastructure and to take the process under control.

Policies to operate education, health, security, social solidarity and social acceptance mechanisms need to be produced and updated. Regardless of the reason, form, type and effect of migration, it continues with a sharp increase and deeply affects the lives of individuals and societies.

Migrants act with two basic motives where they go. The first is to have a good job, the other is to be able to adapt without leaving one's own ethnic group while benefiting from the resources and conditions of the country they are going to.

Migration to developed and high-income countries is the source of migrant cash transactions. These transactions play a role in providing food to many rural households. For poor countries with weak economies, it is provided as insurance in priority areas such as health, food and education. Besides the above, it is also financing support for countries to reduce poverty, investment and development over time.

Migration policies, which are prepared comprehensively and include international agreements, also include processes to be managed well. The ability of the host country to meet migration with an inclusive and institutional system and to position migrants and refugees in a way that will contribute to their capital, skills is the result of strong migration policies. In addition to the 
confrontation of the receiving countries with social and cultural problems, problems such as political, security, health, nutrition and economic congestion and burden increase are seen predominantly. Although the increase in public expenditures by using a significant amount of resources, it has also faced severe damages in security and social life Turkey, since its establishment faced with large waves of migration. Always and under all circumstances, especially against Syrian refugees and asylum seekers, Turkey never hesitate to offer and provide the same opportunities including the rights as well as its citizens have.

\section{Conclusion}

Underlining several risks and opportunities are intertwined, there are data that international migration supports economic growth in receiving countries through various channels such as innovation, capital accumulation, human capital, foreign trade and domestic demand. Security and security issues are issues that need to be kept on the agenda and monitored carefully. The accumulation of refugees in border provinces and big cities causes disruption and insufficiency in health and municipal services and creates a need for additional capacity and budget. Countries that are considered strong in economic, political, social, educational, democratic and conscientious fields should take various measures to avoid the burden of migrants and to remain in the target country 